\title{
Pengaruh Perputaran Modal Kerja dan Likuiditas terhadap Profitabilitas pada Sub Sektor Property dan Real Estate
}

\author{
Komang Tri Wibawa Mahardika ${ }^{*}$, Ni Made Suci² \\ ${ }^{123}$ Program Studi Manajemen, Fakultas Ekonomi, Universitas Pendidikan Ganesha, Singaraja, Indonesia
} *komangtri50@gmail.com ${ }^{1 *}$

\section{Abstrak}

Penelitian ini bertujuan untuk menguji pengaruh simultan dan parsial perputaran modal kerja dan likuiditas terhadap profitabilitas. Rancangan penelitian yang digunakan adalah kuantitatif kausal. Subjek penelitian ini adalah Perusahaan Sub Sektor Property dan Real Estate yang Terdaftar di Bursa Efek Indonesia dan objek penelitian adalah perputaran modal kerja, likuiditas, dan profitabilitas. Populasi penelitian ini adalah perusahaan sub sektor property dan real estate sebanyak 36 perusahaan. Data dikumpulkan dengan pencatatan dokumen, kemudian dianalisis dengan analisis regresi liniear berganda. Hasil penelitian menunjukkan bahwa (1) perputaran modal kerja dan likuiditas berpengaruh signifikan terhadap profitabilitas dengan sumbangan pengaruh sebesar $72,8 \%$, (2) perputaran modal kerja berpengaruh positif dan signifikan terhadap profitabilitas sebesar $63,5 \%$, (3) likuiditas berpengaruh negatif dan signifikan terhadap profitabilitas sebesar $31,1 \%$.

Kata Kunci: Perputaran Modal Kerja, Likuiditas, Profitabilitas

\section{Abstract}

This study aimed to examine the effect simultaneous and partial of working capital turnover and liquidity on profitability. The study design was used quantitative causal. The subject of this study was property and real estate companies listed on the Indonesia Stock Exchange and the object of this study were working capital turnover, liquidity and profitability. The population of this study were 36 companies in the property and real estate sub-sector. Data was collected by documentation recording and analyzed by multiple linear regression analysis. The results showed that (1) working capital turnover and liquidity has significant effect on profitability with a contribution of $72,8 \%$, (2) working capital turnover has positive and significant effect on profitability of 63,5\%, (3) liquidity has negative and significant effect on profitability of 31,1\%.

Keywords: Working Capital Turnover, Liquidity, Profitability

\section{Pendahuluan}

Industri property dan real estate merupakan salah satu industri yang sangat penting bagi kehidupan manusia. Industri property dan real estate pada umumnya merupakan dua hal yang berbeda. Menurut SK Menteri Perumahan Rakyat no.05/KPTS/BKP4N/1995, property adalah tanah hak dan atau bangunan permanen yang menjadi objek pemilik dan pembangunan. Sedangkan menurut peraturan perundang-undangan PDMN No.5 Tahun 1974 yang mengatur tentang industri real estate, Industri real estate adalah perusahaan properti yang bergerak dalam bidang penyediaan, pengadaan, serta pematangan tanah bagi keperluan usaha-usaha industri. Dengan demikian dalam melaksanakan aktivitas sehari-hari, manusia tidak dapat terlepas dari industri ini, misalnya perumahan untuk tempat tinggal dan kantor atau pabrik untuk bekerja.

Pada saat ini perusahaan industri property dan real estate merupakan salah satu perusahaan Go Public yang telah mendaftarkan namanya di Bursa Efek Indonesia. Salah satu

History:
Received: 08 Februari 2021
Revised: 26 Juni 2021
Accepted: 28 Juni 2021
Published: 30 Juni 2021

Publisher: Undiksha Press

Licensed: This work is licensed under

a Creative Commons Attribution 3.0 License 
tujuan pendaftaran tersebut adalah untuk mendapatkan perhatian media sehingga memperoleh sumber pendanaan yang dapat membantu dalam pengembangan usaha di masa depan. Hal ini dapat dilihat dari banyaknya pembangunan dan minat pembeli yang semakin bertambah setiap tahunnya yang secara otomatis akan meningkatkan penjualan dan laba perusahaan di bidang property dan real estate tersebut. Merujuk data dari Badan Kebijakan Fiskal (BKF) Kementerian Keuangan, sektor property dan sektor real estate diperkirakan tetap tumbuh stabil sejalan dengan progres investasi di kedua sektor tersebut. Disebutkan, penerimaan sektoral properti pada 2018 meningkat 6,9\% dibanding 2017.

Keberhasilan suatu perusahaan seringkali dinilai dari besarnya profitabilitas. Profitabilitas adalah kemampuan perusahaan memperoleh laba dalam hubungannya dengan penjualan, total aktiva maupun modal sendiri. Profitabilitas menunjukkan derajat kemampuan perusahaan Go Publik untuk menghasilkan profit atau laba bersih melalui penggunaan semua asset yang dimilikinya (Kasmir, 2015). Penelitian ini mengukur profitabilitas dengan menggunakan Return on Assets (ROA). ROA merupakan salah satu rasio profitabilitas yang dapat mengukur kemampuan menghasilkan laba dari total aktiva yang digunakan. Profitabilitas penting diperhatikan oleh perusahaan, karena jika profitabilitas perusahaan rendah maka akan susah menarik dana dari luar. Begitu pula sebaliknya, profitabilitas yang tinggi dapat mencerminkan kinerja perusahaan yang baik dan menjadi daya tarik bagi investor dan calon investor yang akan membuat perkembangan di sektor property dan real estate lebih maju dan dapat meningkatkan perekonomian negara ke arah yang lebih baik. Analisis mengenai profitabilitas sangatlah penting bagi perusahaan itu sendiri, bagi investor dan perekonomian negara.

Selain itu, untuk kelangsungan usahanya perusahaan haruslah memperhatikan berbagai faktor lain yang berpengaruh terhadap profitabilitas diantaranya perputaran modal kerja dan likuiditas. Profitabilitas perusahaan dapat dimaksimalkan melalui efisiensi terhadap penggunaan sumber daya atau modal kerja perusahaan. Perusahaan perlu modal kerja untuk membiayai kegiatan operasional perusahaan. Untuk mengukur atau menilai keefektivan modal kerja perusahaan selama periode tertentu dapat menggunakan rasio perputaran modal kerja atau working capital turnover (WCT). Secara konsep, semakin cepat perputaran modal kerja maka semakin efisien perusahaan menggunakan modal kerja tersebut, dan pada akhirnya profitabilitas mengalami peningkatan (Pangestuti dan Oetomo, 2016).

Likuiditas adalah rasio yang menggambarkan kemampuan perusahaan dalam memenuhi kewajiban jangka pendek (Kasmir, 2015). Dalam penilitian ini menilai likuiditas menggunakan rasio lancar atau current ratio. Rasio lancar merupakan rasio yang menunjukkan seberapa besar asset yang dibiayai dengan utang. Perusahaan yang memiliki current ratio besar menunjukkan bahwa perusahaan dapat memenuhi kewajiban jangka pendeknya pada saat ditagih. Horne dan Wachowicz (2013) menyatakan likuiditas perusahaan berbanding terbalik dengan profitabilitas. Semakin tinggi likuiditas perusahaan maka kemampuan perusahaan untuk menghasilkan laba semakin rendah.

Subjek yang menjadi fokus dalam penelitian ini yaitu perusahaan sub sektor property dan real estate yang terdaftar di BEI, karena perusahaan tersebut merupakan salah satu sub sektor yang memiliki pertumbuhan profitabilitas lebih rendah dibandingkan dengan sub sektor lain yang ada di sektor property, real estate dan kontruksi bangunan. Rendahnya profitabilitas tersebut menunjukkan bahwa perusahaan belum optimal dalam menghasilkan keuntungan melalui aktiva yang dimiliki, sehingga hal tersebut akan berdampak pada menurunnya kinerja perusahaan. Berdasarkan analisis data laporan keuangan diketahui bahwa tingkat perputaran modal kerja dan likuiditas mengami fluktuasi dan profitabilitas pada perusahaan sub sektor property dan real estate mengalami penurunan di tahun 2017- 
2019. Penurunan profitabilitas perusahaan sub sektor property dan real estate pada tahun 2018 sebesar $0,19 \%$ dan pada tahun 2019 sebesar $1,41 \%$.

Adapun tujuan penelitian ini yaitu untuk menguji dan menganalisis pengaruh: (1) perputaran modal kerja dan likuiditas terhadap profitabilitas pada perusahaan sub sektor property dan real estate yang terdaftar di Bursa Efek Indonesia., (2) perputaran modal kerja terhadap profitabilitas pada perusahaan sub sektor property dan real estate yang terdaftar di Bursa Efek Indonesia., dan (3) likuiditas terhadap profitabilitas pada perusahaan sub sektor property dan real estate .yang terdaftar di Bursa Efek Indonesia.

\section{Hubungan Perputaran Modal Kerja dan Likuiditas Terhadap Profitabilitas}

Horne dan Wachowicz (2009: 254), menyatakan bahwa profitabilitas dapat dicapai jika perusahaan efisien dalam menggunakan modal kerjanya begitupun dengan tingkat likuiditas perusahaan. Artinya likuiditas mempunyai hubungan yang cukup erat dengan kemampuan perusahaan memperoleh laba (profitabilitas), karena likuiditas menunjukkan tingkat ketersediaan modal kerja yang dibutuhkan dalam aktivitas operasional. Jadi dapat disimpulkan bahwa apabila modal kerja digunakan secara efisien maka likuiditas dapat dijaga sehingga akan meningkatkan profitabilitas dan sebaliknya apabila modal kerja digunakan secara tidak efisien maka akan terjadi peningkatan likuiditas sehingga profitabilitas menjadi menurun. Hal ini didukung oleh penelitian yang dilakukan oleh Sariyana dkk (2016), yang menyimpulkan bahwa secara simultan terdapat pengaruh yang signifikan antara perputaran modal kerja dan likuiditas terhadap profitabilitas.

$H_{1}$ : Ada pengaruh perputaran modal kerja dan likuiditas terhadap profitabilitas

\section{Hubungan Perputaran Modal Kerja Terhadap Profitabilitas}

Tunggal (2015) menyatakan indikasi pengelolaan modal kerja yang baik adalah adanya efisiensi modal kerja yang dapat dilihat dari perputaran modal kerja. Perputaran modal kerja dimulai dari saat kas diinvestasikan dalam komponen modal kerja sampai saat kembali menjadi kas. Efisiensi modal kerja berarti bagaimana mengupayakan agar modal kerja yang tersedia tidak kelebihan dan tidak kekurangan.

Untuk menilai efisiensi modal kerja dapat digunakan rasio antara total penjualan dengan rata-rata jumlah modal kerja (Munawir, 2014). Adanya perputaran modal kerja yang tinggi menandakan adanya kesempatan untuk tumbuhnya nilai profitabilitas pada perusahaan yang tinggi untuk masa yang akan datang. Semakin cepat perputaran modal kerja maka semakin efisien perusahaan menggunakan modal kerja tersebut, dan pada akhirnya profitabilitas mengalami peningkatan (Pangestuti dan Oetomo, 2016).

$\mathrm{H}_{2}:$ Ada pengaruh perputaran modal kerja terhadap profitabilitas

\section{Hubungan Likuiditas Terhadap Perputaran Modal Kerja}

Likuiditas adalah kemampuan perusahaan untuk membayar kewajiban-kewajibannya yang segera harus dipenuhi (Sutrisno, 2009: 215). Current ratio (rasio lancar) merupakan rasio yang digunakan untuk mengukur tingkat likuiditas suatu perusahaan. Current ratio merupakan perbandingan antara aktiva lancar dengan hutang lancar (Horne dan Wachowicz, 2013). Likuiditas menjadi acuan yang baik untuk mengetahui aktivitas penggunaan kewajiban lancar dipenuhi dengan aset lancar.

Suatu perusahaan dikatakan likuid apabila perusahaan mampu memenuhi kewajiban jangka pendeknya. Peranan likuiditas sangat penting, karena likuiditas dijadikan sebagai salah satu ukuran yang dapat memberikan kesan pertama tentang baik buruknya suatu perusahaan. Hal ini menunjukkan perusahaan melakukan penempatan dana yang besar pada sisi aktiva lancar. Hal ini sejalan dengan teori Horne dan Wachowicz (2013) yang menyatakan bahwa likuiditas perusahaan berbanding terbalik dengan profitabilitas. 
Maksudnya, semakin tinggi likuiditas perusahaan maka kemampuan perusahaan untuk menghasilkan laba semakin rendah.

$H_{3}$ : Ada pengaruh likuiditas terhadap profitabilitas

\section{Metode}

Penelitian ini menggunakan rancangan penelitian kuantitatif kausal yang digunakan untuk memperoleh eksplanasi yang teruji mengenai pengaruh perputaran modal kerja dan likuiditas terhadap profitabilitas. Sugiyono (2007: 12) menyatakan, desain kausal adalah hubungan yang bersifat sebab akibat. Dengan kata lain desain kausal adalah desain penelitian yang bertujuan untuk menentukan hubungan dan pengaruh dari suatu variabel terhadap variabel lainnya.

Subjek dalam penelitian ini yaitu perusahaan sub sektor property dan real estate yang terdaftar di Bursa Efek Indonesia, sedangkan objek penelitian ini yaitu perputaran modal kerja, likuiditas dan profitabilitas. Penelitian ini menggunakan populasi sebanyak 36 perusahaan sub sektor perdagangan besar. Jenis data yang digunakan dalam penelitian ini adalah data kuantitatif dan sumber data dalam penelitian ini adalah data sekunder.

Teknik pengumpulan data yang digunakan penulis dalam penelitian ini yaitu metode pencatatan dokumen dengan mengumpulkan, mencatat serta mengkaji data keuangan tahunan. Penelitian ini menggunakan metode analisis regresi linier berganda dengan menggunakan alat bantu program komputer Statistical Package for Sosial Science 23.0 for Windows. Metode ini digunakan untuk mengetahui seberapa besar variabel independen perputaran modal kerja dan likuiditas memengaruhi variabel dependen profitabilitas. Sebelum melakukan analisis regresi linier berganda, terlebih dahulu harus memenuhi uji asumsi klasik yang meliputi: (1) uji multikolonieritas, (2) uji autokorelasi, (3) uji heteroskedastisitas dan (4) uji normalitas.

\section{Hasil dan Pembahasan}

Berdasarkan hasil pengujian Statistical Package for Sosial Science 24.0 for Windows diperoleh hasil pengujian berupa ringkasan hasil output SPSS seperti nampak pada Gambar 1.

Struktur hubungan pengaruh perputaran modla kerja dan likuiditas terhadap profitabilitas nampak pada Gambar 1.

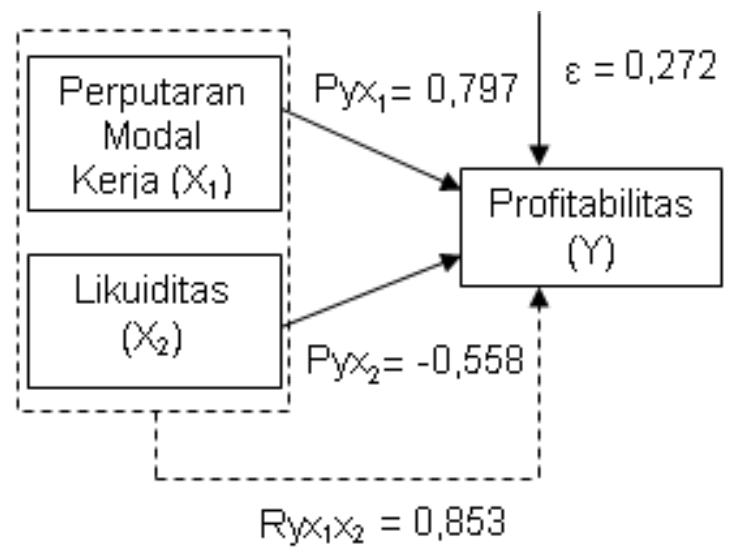

Gambar 1. Struktur Hubungan Pengaruh Perputaran Modal Kerja dan Likuiditas Terhadap Profitabilitas

Berdasarkan hasil uji regresi linier berganda menunjukkan nilai Ryx1x2 $=0,853$ dengan p-value $\neg 0,000<\alpha=0,05$, sehingga H0 ditolak artinya ada pengaruh simultan dari perputaran modal kerja dan likuiditas terhadap profitabilitas pada perusahaan sub sektor 
property dan real estate yang terdaftar di Bursa Efek Indonesia periode 2017 - 2019. Besarnya sumbangan pengaruh simultan dari perputaran modal kerja dan likuiditas terhadap profitabilitas yaitu 0,728 atau $72,8 \%$.

Berdasarkan hasil uji regresi linier berganda menunjukkan nilai Pyx $1=0,797$ dengan pvalue $\neg 0,000<\alpha=0,05$, sehingga $\mathrm{H} 0$ ditolak yang artinya ada pengaruh parsial dari perputaran modal kerja terhadap profitabilitas pada perusahaan sub sektor property dan real estate yang terdaftar di Bursa Efek Indonesia periode 2017 - 2019. Besarnya sumbangan pengaruh perputaran modal kerja terhadap profitabilitas yaitu 0,635 atau 63,5\%. Besarnya pengaruh pertumbuhan likuiditas Pyx $2=-0,558$ dengan p-value $\neg 0,000<\alpha=0,05$, sehingga H0 ditolak artinya ada pengaruh parsial dari likuiditas terhadap profitabiltas pada perusahaan sub property dan real estate yang terdaftar di Bursa Efek Indonesia periode 2017 - 2019. Besarnya sumbangan pengaruh likuiditas terhadap profitabilitas yaitu sebesar 0,311 atau $31,1 \%$.

Berdasarkan hasil uji regresi linier berganda diperoleh nilai konstanta $(\alpha)$ sebesar 2,235, nilai koefisien regresi perputaran modal kerja $(\beta 1)$ sebesar 0,310 , dan nilai koefisien regresi likuiditas $(\beta 2)$ sebesar $-0,152$ serta error term $(\varepsilon)$ sebesar 0,271 , sehingga persamaan regresi dalam peneilitian ini diformulasikan sebagai berikut.

$\mathrm{Y}=2,235+0,310 \mathrm{X} 1-0,152 \mathrm{X} 2+0,271$

Interpretasi hasil analisis regresi linier berganda dalam penelitian ini yaitu sebagai berikut. (1) Nilai konstanta sebesar 2,235 artinya apabila nilai koefisien perputaran modal kerja dan likuiditas sama dengan 0, maka nilai profitabilitas yaitu 0,340. (2) Nilai koefisien perputaran modal kerja $(\beta 1)$ yaitu 0,310 berpengaruh positif terhadap profitabilitas. Hal ini berarti bahwa setiap perputaran modal kerja naik satu satuan, maka profitabilitas mengalami peningkatan sebesar 0,310 dengan asumsi bahwa variabel lainnya tetap. (3) Nilai koefisien likuiditas $(\beta 2)$ yaitu $-0,152$ berpengaruh negatif terhadap profitabilitas. Hal ini berarti bahwa setiap kenaikan satu satuan likuiditas, maka profitabilitas mengalami penurunan sebesar 0,152 dengan asumsi bahwa variabel lainnya tetap. (4) Nilai error sebesar 0,272 dengan asumsi bahwa masih ada variabel lain yang mempengaruhi profitabilitas selain perputaran modal kerja dan likuiditas.

Perputaran modal kerja dan likuiditas berpengaruh signifikan terhadap profitabilitas pada perusahaan sub sektor property dan real estate yang terdaftar di Bursa Efek Indonesia. Hasil penelitian ini mendukung teori yang disampaikan oleh Horne dan Wachowicz (2009: 254), yang menyatakan bahwa profitabilitas dapat dicapai jika perusahaan efisien dalam menggunakan modal kerjanya begitupun dengan tingkat likuiditas perusahaan. Artinya likuiditas mempunyai hubungan yang cukup erat dengan kemampuan perusahaan memperoleh laba (profitabilitas), karena likuiditas menunjukkan tingkat ketersediaan modal kerja yang dibutuhkan dalam aktivitas operasional. Jadi dapat disimpulkan bahwa apabila modal kerja digunakan secara efisien maka likuiditas dapat dijaga sehingga akan meningkatkan profitabilitas dan sebaliknya apabila modal kerja digunakan secara tidak efisien maka akan terjadi peningkatan likuiditas sehingga profitabilitas menjadi menurun. Kajian emperik yang turut mendukung temuan penelitian ini adalah hasil penelitian yang dilakukan oleh Sariyana dkk (2016), yang menyimpulkan bahwa secara simultan terdapat pengaruh yang signifikan antara perputaran modal kerja dan likuiditas terhadap profitabilitas.

Perputaran modal kerja berpengaruh positif dan signifikan terhadap profitabilitas pada perusahaan sub property dan real estate yang terdaftar di Bursa Efek Indonesia. Hasil menunjukkan apabila variabel perputaran modal kerja mengalami kenaikan maka akan diikuti kenaikan profitabilitas. Hasil penelitian ini sejalan dengan Pangestudi dan Oetomo (2016) yang menyatakan secara konsep bahwa semakin cepat perputaran modal kerja maka semakin efisien perusahaan menggunakan modal kerja tersebut, dan pada akhirnya profitabilitas mengalami peningkatan. Perputaran modal kerja sangat diperlukan untuk menjamin 
keberhasilan jangka panjang perusahaan dan untuk mencapai tujuan perusahaan secara keseluruhan yang dalam hal ini mampu memperbesar profitabilitas. Kondisi perputaran modal kerja dalam suatu perusahaan dapat dipengaruhi oleh modal kerja (aktiva lancar dan hutang lancar) dalam menghasilkan penjualan. Semakin tinggi volume penjualan yang dihasilkan maka modal kerja berputar semakin cepat sehinggga mampu meningkatkan profitabilitas. Penelitian ini memperkuat penelitian terdahulu yang dilakukan oleh Fuad, dkk (2019) dan Wibowo (2012) menemukan perputaran modal kerja berpengaruh positif terhadap profitabilitas.

Likuiditas berpengaruh negatif dan signifikan terhadap profitabilitas pada perusahaan sub sektor property dan real estate yang terdaftar di Bursa Efek Indonesia. Hasil ini menunjukkan apabila variabel likuiditas mengalami kenaikan maka akan diikuti penurunan profitabilitas, sebaliknya apabila likuiditas mengalami penurunan maka akan diikuti kenaikan profitabilitas. Hasil ini sejalan dengan teori dari Horne dan Wachowicz (2013), yang menyatakan bahwa likuiditas perusahaan berbanding terbalik dengan profitabilitas. Maksudnya, semakin tinggi likuiditas perusahaan maka kemampuan perusahaan untuk menghasilkan laba semakin rendah. Likuiditas dapat dilihat dari nilai current ratio pada perusahaan sub sektor property dan real estate. Semakin besar nilai current ratio, maka semakin besar kemampuan perusahaan memenuhi kewajiban jangka pendeknya. Hal ini menunjukkan perusahaan melakukan penempatan dana yang besar pada sisi aktiva lancar. Penempatan dana yang besar pada sisi aktiva akan memiliki dua efek, yakni likuiditas perusahaan pada sub sektor property dan real estate akan semakin baik, namun di satu sisi perusahaan sub sektor property dan real estate akan kehilangan kesempatan memperoleh profitabilitas, dikarenakan penempatan dana yang akan digunakan sebagai investasi dicadangkan untuk memenuhi likuiditas. Penelitian ini memperkuat penelitian terdahulu yang dilakukan oleh Rahmawati \& Kholiq (2018) dan Wahyuliza \& Dewita menemukan likuiditas berpengaruh negatif terhadap profitabilitas.

\section{Simpulan dan Saran}

Berdasarkan hasil pengujian statistik dan hipotesis serta pembahasan yang telah dipaparkan pada bab sebelumnya, maka dapat ditarik beberapa kesimpulan sebagai berikut. (1) Perputaran modal kerja dan likuiditas berpengaruh signifikan terhadap profitabilitas pada perusahaan sub sektor property dan real estate yang terdaftar di Bursa Efek Indonesia, (2) perputaran modal kerja berpengaruh positif dan signifikan terhadap profitabilitas pada perusahaan sub sektor property dan real estate yang terdaftar di Bursa Efek Indonesia, (3) likuiditas berpengaruh negatif dan signifikan terhadap profitabilitas pada perusahaan sub sektor property dan real estate yang terdaftar di Bursa Efek Indonesia.

Berdasarkan hasil pembahasan dan simpulan yang telah dipaparkan sebelumnya, maka dapat diajukan beberapa saran sebagai berikut. (1) Bagi pihak perusahaan sub sektor property dan real estate, diharapkan bagi pihak manajemen perusahaan sub sektor property dan real estate yang terdaftar di Bursa Efek Indonesia, agar lebih meningkatkan perputaran modal kerja dan mengontrol likuiditas agar tetap stabil dalam upaya untuk meningkatkan profitabilitas, karena penelitian ini membuktikan bahwa perputaran modal kerja dan likuiditas dapat mempengaruhi profitabilitas. (2) Bagi peneliti selanjutnya, peneliti selanjutnya yang tertarik untuk mengkaji aspek yang serupa yaitu perputaran modal kerja, likuiditas, dan profitabilitas diharapkan untuk mengembangkan penelitian ini dengan menggunakan populasi dan sampel yang lebih luas agar hasil penelitian lebih teruji keandalannya. Di samping itu, diharapkan untuk menguji variabel lain yang diduga kuat dapat mempengaruhi profitabilitasform. 


\section{Daftar Pustaka}

Anggarsari, Lovi dan Tony Seno Aji. 2018. "Pengaruh Ukuran Perusahaan, Leverage, Likuiditas, Perputaran Modal Kerja Dan Pertumbuhan Penjualan Terhadap Profitabilitas(Sektor Industri Barang Dan Konsumsi Yang Terdaftar Di Bursa Efek Indonesia Periode 2013-2016”. Jurnal Ilmu Manajemen, Vol. 6, No. 4.

Bursa Efek Indonesia. 2017. Statistic Indonesia Stock Exchange (IDX). Terdapat di www.idx.co.id (diakses tanggal 8 September 2020).

Bursa Efek Indonesia. 2018. Statistic Indonesia Stock Exchange (IDX). Terdapat di www.idx.co.id (diakses tanggal 8 September 2020).

Bursa Efek Indonesia. 2019. Statistic Indonesia Stock Exchange (IDX). Terdapat di www.idx.co.id (diakses tanggal 8 September 2020).

Danang, Sunyoto. 2013. Metodologi Penelitian Akuntansi. Bandung: PT. Refika Aditama.

Fuad, Muhammad, dkk. 2019. "Pengaruh Perputaran Modal Kerja, Operating Leverage dan Financial Leverage terhadap Profitabilitas Perusahaan Sektor Retail di Bursa Efek Indonesia”. Jurnal Konsep Bisnis Dan Manajemen, Vol. 5, No. 2, ISSN: 2407-2648.

Ghozali, Imam. 2009. Aplikasi Analisis Multivariate dengan Program SPSS. Semarang: Badan Penerbit Universitas Diponegoro.

Hanafi, Halim. 2016. Analisis Laporan Keuangan. Edisi Kelima. Cetakan Pertama. Yogyakarta.

Horne, James C. Van dan John M. Machowicz. 2009. Prinsip-Prinsip Manajemen Keuangan, Jakarta: Salemba Empat.

Horne, James C. Van dan John M. Wachowicz. 2013. Prinsip-prinsip Manajemen Keuangan. Edisi 13. Buku 1. Jakarta: Salemba Empat.

Iskandar, Tania, dkk. 2014. "Pengaruh Perputaran Modal Kerja, Struktur Modal Dan Likuiditas Terhadap Profitabilitas Perusahaan Industri \& Chemical di Bursa Efek Indonesia". Jom Fekon, Vol. 1, No. 2.

Kasmir. 2015. Analisis Laporan Keuangan. Jakarta: PT Raja Grafindo Persada.

Kholifah, Umi dan Erwin Dyah A. 2016. "Analisis Pengaruh Efisiensi Modal Kerja, Likuiditas dan Solvabilitas terhadap Profitabilitas pada Perusahaan Industri Barang Konsumsi yang Terdaftar di Bursa Efek Indonesia (BEI) Periode 2011-2014”. Jurnal Ekonomi Manajemen, Vol. 1, No. 1.

Kusuma, Robi Pramana. 2016. "Pengaruh Dar, Ukuran Perusahaan, Risiko, Pajak,Dan Likuiditas Terhadap Profitabilitas perusahaan Sektor Pertambangan Di Indonesia". Jurnal Bisnis dan Manajemen, Vol. 8 , No. 2.

Mailinda, Riska, dkk. 2018. "Pengaruh Leverage, Likuiditas Dan Ukuran Perusahaan Terhadap Profitabilitas Pada Bni Syariah Di Indonesia Periode 2015-2017”. Jurnal Ilmiah Mahasiswa Ekonomi Manajemen, Vol. 3, No. 4, E-ISSN: 2598-635X.

Munawir. 2014. Analisa Laporan Keuangan. Edisi Keempat. Cetakan Ketiga Belas. Liberty. Yogyakarta.

Pangestuti, C.D.A. dan Oetomo, H.W. (2016). Pengaruh Perputaran Modal Kerja, Ukuran Perusahaan, Operating Leverage dan Financial Leverage terhadap Profitabilitas. Jurnal Ilmu \& Riset Manajemen.

Rachminiar, Erna Siti dan Khairunnisa. 2018. "Pengaruh Perputaran Modal Kerja dan 
Likuiditas terhadap Profitabilitas (Studi Kasus pada Perusahaan Makanan dan Minuman yang Terdaftar di BEI periode 2013-2016)". e-Proceeding of Management, Vol.5, No.3, ISSN: 2355-9357.

Rahmawati, Irma dan Mohammad Kholiq Mahfudz1. 2018. “Analisis Pengaruh Perputaran Modal Kerja, Likuiditas, Struktur Modal, Sales Growth, Struktur Aktiva, Size Terhadap Profitabilitas (Studi Pada Perusahaan Manufaktur Yang Terdaftar Di Bursa Efek Indonesia Tahun 2012-2016)". Diponegoro Journal Of Management, Vol. 7, No. 4, ISSN: 2337-3792.

Sariyana, Bagus Mangdahita, dkk. 2016. Pengaruh Perputaran Modal Kerja Dan Likuiditas Terhadap Profitabilitas (Studi Pada Perusahaan Food And Beverages). e-Journal Bisma Universitas Pendidikan Ganesha, Vol. 4.

Sugiyono. 2007. Metode Penelitian Bisnis. Bandung: Alfabeta.

Sutrisno. 2009. Manajemen Keuangan Teori, Konsep dan Aplikasi. Yogyakarta : Penerbit Ekonisia.

Tunggal, W. (2015). Dasar-dasar Analisis Laporan Keuangan. Yogyakarta: Rhineka Cipta.

Vemonica. Gambaran Umum industri real estate industri. Di https://www.coursehero.com/file/16293730/real-estate/ (akses 28 april 2020).

Wahyuliza, Suci dan Nola Dewita. 2018. "Pengaruh Likuiditas, Solvabilitas Dan Perputaran Modal Kerja Terhadap Profitabilitas Pada Perusahaan Manufaktur Yang Terdaftar Di Bursa Efek Indonesia”. Jurnal Benefita.

Wibowo, Agus dan Sri Wartini. 2012. "Efisiensi Modal Kerja, Likuiditas Dan Leverage Terhadap Profitabilitas Pada Perusahaan Manufaktur Di Bei". Jurnal Dinamika Manajemen, Vol. 3, No. 1, ISSN: 2086-0668.Kotler, P., \& Amstrong, G. (2012). Principles of Marketing. New Jersey: Prenctice Hall. 